\title{
An Empirical Research on the Correlation between Human Capital and Career Success: Serbian and Macedonian Banking Sector
}

\author{
Tatjana Boshkov, $\mathrm{PhD}^{1^{*}}$ \\ Gligor Bishev, PhD2 \\ Zarko Rađenović, $\mathrm{MsC}^{3}$ \\ Aleksandra Zezova, $\mathrm{PhD}^{4}$ \\ 1 Professor at Faculty of Tourism and Business Logistics, University "Goce Delcev", Stip, Macedonia \\ ${ }^{*}$ Corresponding Author Email: tatjana.boshkov@gmail.com \\ 2 University Professor and Executive Director and Chairman of the Board, Sparkasse Bank, Macedonia \\ Email: Gligor.Bishev@sparkasse.mk \\ ${ }^{3} \mathrm{PhD}$ student, Economics Faculty University of Nis, Serbia \\ Email: zarkoradjenovic@hotmail.com \\ ${ }_{4}^{4}$ Professor at Faculty of Tourism and Business Logistics, University "Goce Delcev", Stip, Macedonia, \\ Email: aleksandra.zezova@ugd.edu.mk
}

Doi:10.5901/mjss.2017.v8n1p279

\begin{abstract}
Understanding the impact of human capital on the achievement of career success is essential for each individual in turbulent times on the labor market. Banking sector also is human capital intensive and plays a critical role for the banks in meeting their goals and offering services to its clients. In the current era of technology, globalization and the general progress principles of "knowledge economy" are ruling. So, each individual in the labor market who wants to build own career, should work on continuous improvement of human capital. This helps their recognition in the increasingly competitive labor market, which eliminates "weak players" since their inability to adapt the modern trends and staff needs. The paper determines that human resource management (HRM) in banking sector must embrace strategic human resource planning programs with all banks strategy. This underlines the essential meaning of designing an effective recruitment policy with these strategies as formulation and implementation of active reward policy. Also, banks should include more active training and development for employees. This paper presents a statistical analysis of the correlation mentioned categories, based on 474 employees, in Serbian and Macedonian banking sector. Analyses such as Chi-square test, Mann-Whitney U, Kolmogorov-Smirnov Z test and linear regression, proving the significance impact of the development of employees' human capital on career success, viewed through different hierarchical positions in a particular sector.
\end{abstract}

Keywords: HRM, banking sector, Chi-square test, Mann-Whitney U, Kolmogorov-Smirnov Z test, Linear regression

\section{Introduction}

Creating a better and more diverse sets or portfolio of skills and knowledge is certainly the most important problem of every person with a specific vocational profile. This is because the investment in improving the knowledge and skills creates a better position in the labor market, and therefore the possibility of making more money. Increased awareness of these intangible assets owned by an individual and the organization he works for, it attempted to define and clarify the notion of the kind of "invisible" capital.

The literature in the field of human resource management is increasingly aware of the need to understand human resource management systems. Human resource systems are basis for improving the quality of services in banking sector.

Pfeffer (1994) said that having good human resource management is likely to generate much loyalty, commitment or willingness to expend extra effort for the organizations" objectives".

Human capital is the level of knowledge and skills that are recommended and characterized by one employee and thus determine its contribution to the productivity of an organization as well as the size of his earnings. The success of his career, in addition to objective criteria based on knowledge and values that make human capital, can be defined as a 
positive psychological feeling connected with the achievements at work. Thus, the success in his career initiated human capital can be divided into two groups:

- objective for career success relating to the level of income and realized the position in the hierarchy of the organization.

- $\quad$ subjective success for career pertaining to satisfaction with the job.

The aim of the research refers to empirical confirmation the significance of human capital impact on the career success and fact that factors that influence on development of human capital influence on the career development, too. The research was conducted on the basis of questionnaire in banks and / or branches of banks operating in the Republic of Serbia and Republic of Macedonia. According to the questions in this questionnaire, the employees in the banking sector (474) have expressed their views on various aspects of human capital and their affect on career.

In banking sector, all employees are expected to be high performers. So, human resource practices are revisited, thus HRM is one of the banks functions that have experienced significant changes over the last few decades. The current disposition of HRM is largely associated with the drastic expansion of businesses globally, technological innovations and fierce competition that characterizes the environment in which businesses operate today and Macedonian and Serbian banking sector are no exception from this global development.

\section{Literature Review}

The literature in the field of human resource management is focusing on effectively managing human resources of organizations. This is the reason why managers of the organizations are interested in better knowing human resource practices for enhancing employee (Boselie et al. 2001; Den Harrtog and Verburg 2004). According to these HRM practices, Teseema \& Soeters (2006) have studied eight of them. These eight practices are recruitment and selection, training, placement, compensation, employee evaluation, promotion, grievance procedure and pension or social security.

Human Resource Management (HRM) has made a move from a state of insignificance to one of strategic importance academically and business wise (Schuler et al. 1993; Teagarden and Von Glinow 1997). The increasing interest in human resources is due to the assumption that employees and the way they are managed is critical to the success of organization and can be a source of sustainable competitive advantage (Lado and Wilson 1994; Wright et al.1994). Stone (1998) remarks that "human resource management is either part of the problem or part of the solution in gaining the productive contribution of people". Further, a career success is defined as a progress of a person with its activities. So, a career can have an employee in one company or more. Employee also plans his career. He is guided by certain attitudinal syndromes, needs values and talents (Schein, 1978).

\section{Research Methodology}

This study investigates the factors that influence on the development of human capital and their relative rankings depending on position of the employee in the organization (corporate culture, employee advancement and career success planning). Regarding the characteristics of the sample, the employees who participated in the survey were of different ages, genders and various positions in the organization or its sectors. In order to better understands the significance of the impact of human capital on the career success and the perception of employees about this issue, respondents were employees of various departments and sectors that in turn perform different types of jobs (from counter workers, clericals, field agents, top management).

Statistical analysis was based on the questionnaire and number of procedures which according to the authors are the best instrumentation of nonparametric tests for assessing the factors correlation between development of human capital, career success and position of employees in the organization. This analysis is included the following procedures (which will in upcoming text be detailed processed):

- $\quad$ Chi-square test

- Mann-Whitney U test

- $\quad$ The Kolmogorov-Smirnov Z test

- Linear regression.

\section{Hypothesis Confirmation and Discussion about Results of Research}

After conducting a survey and collected data analyzes were performed using the statistical program (SPSS) and the first in the series is a chi square test. This non-parametric techniques, among other things deals with the analysis of the 
statistical significance of the connection between two or more variables. It is necessary first to set hypothesis on which this technique is based:

- $\quad$ H0- Each factor that affects the development / level of human capital does not affect the same success in his career

- H1- Each factor that affects the development / level of human capital affects the same success in his career.

Based on the obtained indicators from the chi-square statistic and the significance level that is greater than 0.05 can be observed that this confirms the null hypothesis that says different factors of human capital differently influence the success in his career. Also, based on experience it is estimated that the value of Phi- Cramer's V coefficients indicate a low correlation between variables when it comes to their impact on the success of his career. This again means that, depending on the position in the organization and the level of competence of employees, various factors of development of human capital have different importance (low correlation between variables ranging from 0 to 0.3 ).

Chi-Square Tests

\begin{tabular}{|c|c|c|c|}
\hline & Value & df & $\begin{array}{c}\text { Asxone, Sig. (2- } \\
\text { sided) }\end{array}$ \\
\hline Pegrson Chi-Square & $2.877^{\circ}$ & 4 & .579 \\
Likelihood Ratio & 2.882 & 4 & .578 \\
Linear-by-Linear Association & .177 & 1 & .674 \\
N of Valid Cases & 474 & & \\
\hline
\end{tabular}

9. 0 cells $(.0 \%)$ have expected count less than 5 . The minimum expected count is 6.27 .

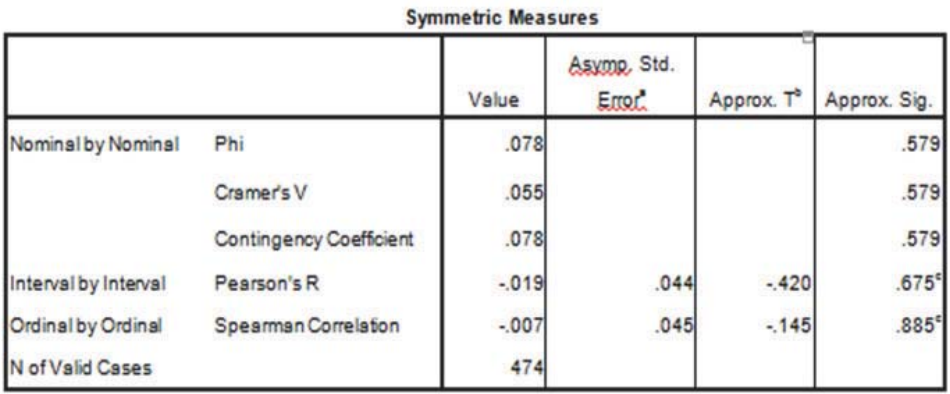

Source: Authors' results based on available data

Given that the aforementioned Mann-Whitney $U$ test is concluded that the different positions of employees differently ranked individual factors of human capital. In other words, the different positions of employees attach different importance factors affecting human capital. Thus, the null hypothesis is proved that in this case means that lower levels of employees (common officers, tellers) attach much more importance to factors of human capital development and success in the career than top management, which is in the highest position. A sample of observations is greater than 30 , the statistical program calculates the statistics (Wilcoxon), which in this way proves that there are differences in the ranking factors for the development of human capital between categories of employees $(z=-0.42, p=0.67)$. As far as the KolmogorovSmirnov $Z$ test that defines normality distribution of data, we can say that there is a certain moderate deviation from normality considering that this value should aim to 0 . With an additional logarithmic transformation of variables or a square function may affect the distribution, asymmetry and depth, because of mathematical simplicity will be examined in this paper. 


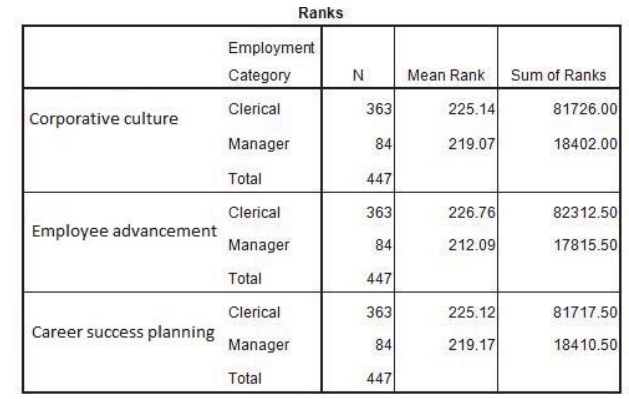

Test Statistics

\begin{tabular}{|l|r|r|r|}
\hline & \multicolumn{1}{|c|}{$\begin{array}{c}\text { Corporative } \\
\text { culture }\end{array}$} & $\begin{array}{c}\text { Employee } \\
\text { advancement }\end{array}$ & \multicolumn{1}{c|}{$\begin{array}{c}\text { Career success } \\
\text { planning }\end{array}$} \\
\hline Mann-WhitneyU & 14832.000 & 14245.500 & 14840.500 \\
Wilcoxon W & 18402.000 & 17815.500 & 18410.500 \\
Z & -.423 & -1.001 & -.413 \\
Asymp. Sig. (2-tailed & .672 & .317 & .680 \\
\hline
\end{tabular}

Test Statstics ${ }^{\mathrm{a}}$

\begin{tabular}{|ll|r|r|r|}
\hline & & $\begin{array}{c}\text { Corporative } \\
\text { culture }\end{array}$ & $\begin{array}{c}\text { Employee } \\
\text { advancement }\end{array}$ & $\begin{array}{l}\text { Career } \\
\text { success } \\
\text { planning }\end{array}$ \\
\hline Most Extreme Absolute & .061 & .080 & .056 \\
Differences & Positive & .004 & .000 & .002 \\
& Negative & -.061 & -.080 & -.056 \\
Kolmogorov-SmirnovZ & .505 & .657 & .459 \\
Asymp. Sig. (2-tailed) & .961 & .780 & .984 \\
\hline
\end{tabular}

a. Grouping Variable: Employment Category

Source: Authors' results based on available data

When we are talking about linear regression which is applied to the analysis of data obtained from the survey, there are several important things that should be observed when interpreting the results on the significance of the factors that affect the development / level of human capital, the strength of their correlations and relationships with other variables. In this regression model, as the dependent variable was taken employment categories, which are explained previously, carried out the division of employees into three groups (ordinary officials, heads of certain functions within the bank's top management). Thus, the observation how the dependent variable is correlated with the independent variables in the regression model, which has four (corporate culture, career advancement, success in career planning and the actual salary).

The following tables of regression model, which in this case examined what impact on certain categories of employees have certain factors of development of human capital, are the most important when it comes to interpreting the results. The multiple correlation coefficient $R$, which shows a linear correlation between the original values of the dependent variable and the model predicted values of the dependent variable is 0.780 , which indicates a very strong relationship. The coefficient of determination shows that over $60 \%$ of the variability category of employees can be explained by the regression model, or independent variables that belong to the human capital. The adjusted coefficient of determination $(0.605)$ is very close, almost identical to the value of the ordinary coefficient of determination, due to the favorable ratio of independent variables and the total number of respondents - observations (the number of independent variables is 4 , and the number of observations 474 ).

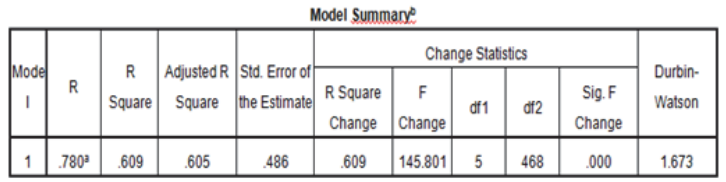

Source: Authors' results based on available data 
As for the ANOVA procedure within the regression model it examines the validity of a regression model with the statistical population. This is about proving the hypothesis that:

$\mathrm{H} 0: \mathrm{R} 2=0$ or $\mathrm{H} 1: \mathrm{R} 2 \neq 0$

Based on the output results of the column Sig. $=0.000$ conclusion is that the null hypothesis is rejected, and that the coefficient of determination is greater than 0 and which is established. This is to certify that the regression model explains a significant amount of variability in the dependent variable.

\begin{tabular}{|c|c|c|c|c|c|c|}
\hline \multicolumn{7}{|c|}{ ANOVA' } \\
\hline & Model & $\begin{array}{l}\text { Sum of } \\
\text { Squares }\end{array}$ & dt & Mean Square & $\mathrm{F}$ & Sig. \\
\hline \multirow{3}{*}{1} & Regression & 172.219 & 5 & 34.444 & 145.801 & $.000^{3}$ \\
\hline & Residual & 110.559 & 468 & .236 & & \\
\hline & Total & 282.778 & 473 & & & \\
\hline
\end{tabular}

Source: Authors' results based on available data

In the final table of coefficients observed standardized beta coefficients representing the height of the significance of the influence of some independent variables on the dependent variable. In fact, these coefficients are reduced independent variables on the same phenomenon, so that all independent variables treated in the same way with the same scale evaluation. Logically, some values of $\beta$ coefficients are negative which is in the line with correlation coefficients from the results presented above. Regarding the factors affecting the level of human capital is slightly larger corporate culture takes precedence in relation to career advancement and success in career planning. The high value of the coefficient $\beta$ for the current salary as an independent variable, that variable as the numerical predispositions and other specifics of these different factors of human capital, it is expected. This is due to the fact that the salary in some way and points out the differences in the hierarchy of an organization.

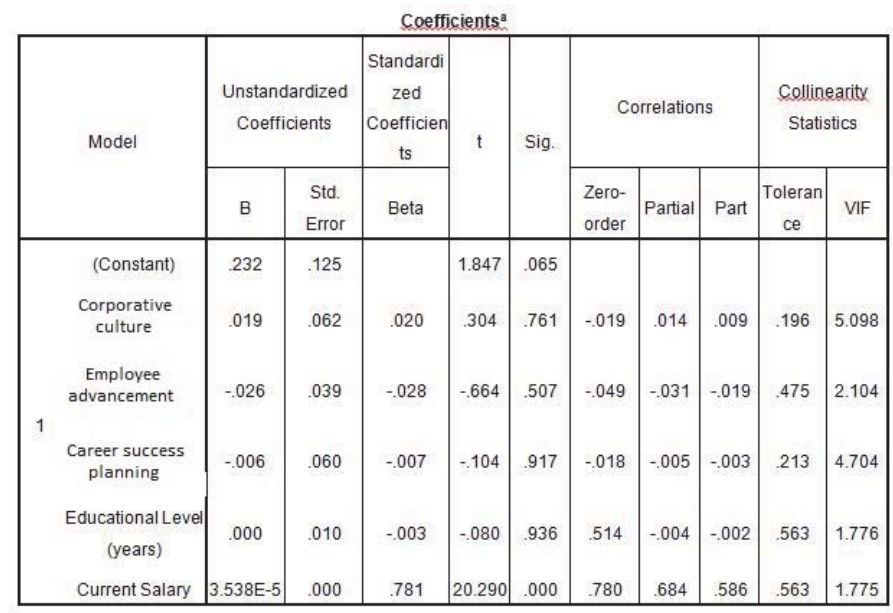

Source: Authors' results based on available data

\section{Conclusion}

Developed countries have long known that the human capital is the biggest asset they have. Even in many marketing analysis, the element of "people" ranks among the major elements of marketing programs that ensure success in the market (product, promotion, distribution, pricing, packaging, planning, people ...). With each loss even the smallest part of the human capital which the organization has, it loses part of its knowledge, which essentially represents a certain way of reducing the competitive advantage. Therefore, the main development trend of the organization should be, in addition to other activities, the creation, development, sustainability and preservation of human capital at its disposal. Career 
planning plays a major role towards enhancing realization of increased financial performance of banking institutions. Career planning has to be concerned with the management of diversity. Career plans must therefore recognize that banks staff should receive recognition as individuals with unique needs, wants, and abilities; individuals are more motivated by an organization that responds to their aspirations and needs; individuals can grow, change and seek new directions if they are given the right opportunities, encouragement and guidance. Banks human resource management should strive towards promotion of better relations between employees in order to create a friendly working environment. This leads to increased level of employees' engagement in the execution of banks job task functions hence contributing towards realization of increased banks financial performance.

Talking in this paper about the human capital together with all its accompanying elements, could be conclude that it is one important link in the business of specific organizations but also link that makes employees more productive and successful in their career paths. Only employees with a strong potential of their own human capital for career success can create a work atmosphere that brings results.

The paper determines that human resource management (HRM) in banking sector must embrace strategic human resource planning programs with all banks strategy. This underlines the essential meaning of designing an effective recruitment policy with these strategies as formulation and implementation of active reward policy. Also, banks should include more active training and development for employees.

\section{References}

Arthur, M.B., Khapova, S.N., Wilderom, C.P.M., (2005) Career success in boundaryless career world ,Journal of Organizational Behavior, vol.26,no.2, p.177-202.

Ballout, H.I., (2007), Career success, Journal of Managerial Psychology, Vol. 22 Iss 8 p. 741- 765

Boselie, P., Paauwe, J. and Jansen, P.J. (2001a), Human Resource Management and Performance: Lessons from the Netherlands. International Journal of Human Resource Management, Vol.12, 1107-25.

Den Hartog, D.N. and Verburg, R.M. (2004), High Performance Work Systems, Organizational Culture and firm Effectiveness. Human Resource Management Journal, Vol.14:1, 55-78.

Drucker, P. F. (1999a), "Knowledge-worker productivity: the biggest challenge", California Management Review, Vol. 41 No. 2, p. $79-94$.

Eby, L.T., Butts, M., Lockwood, A., (2003) Predictors of success in the era of boundaryless careers,Journal of Organizational Behavior, , vol.24,no.5, p. $689-708$.

Fu, J.C., Fu, P. (2008) Study of the Relationship between human capital and occupational mobility: the role of human capital. Chinese Journal of Ergonomics, vol.14, no3, p.36-40.

Greenhaus, J. H., Parasuraman, S., Wormley, W., (1990) Effects of race on organizational experiences, job performance evaluations, and career outcomes, Academy of Management Journal, vol.33, p.64-86.

Guo,W., Xiao, H., Yang, X., (2012) An Empirical Research on the Correlation between Human Capital and Career Success of Knowledge Workers in Enterprise, International Conference on Solid State Devices and Materials Science, Faculty of Management and Economics, Dalian, China

Heslin, P.A., (2005) Conceptualizing and evaluating career success, Journal of Organizational Behavior, p.113-136

Lado, A.A. and Wilson, C.M. (1994), Human Resource Systems and Sustained Competitive Advantage, A Competency-Based Perspective, Academy of Management, Review, Vol.19, 699-727.

Pfeffer, J. (1994), Competitive Advantage through People: Unleashing the Power of the Work Force, Boston, MA: Havard Business School Press.

Schein, E. H. (1978). Career Dynamics: Marching Individual and Organization Needs. Reading, MA: Addison-Wesley.

Schuler, R.S., Dowling, P.J., \& De Cieri, H. (1993), An Integrative Framework of Strategic International Human Resource Management. Journal of Management, Vol.19, 419-459.

Stone, R. (1998), Human Resource Management. New York: Wiley.

Teagarden, M.B \& Von Glinow, M.A (1997), Human Resource Management in Cross Cultural Context: Emic Practices versus Etic Philosophies". Management International Review, Vol.37:1, 7-20.

Tessema M, Soeters J (2006), Challenges and prospects of HRM in developing countries: testing the HRM-performance link in Eritrean civil service. Int. J. Hum. Resource Management, Vol.17:1, 86- 105.

Wright, P.M., McMahan, G.C. and McWilliams, A. (1994), Human Resources and Sustained Competitive Advantage: A Resource-based Perspective. International Journal of Human Resource Management, Vol. 5, No.2, 301-326. 